\title{
Keratinase Production by Three Bacillus spp. Using Feather Meal and Whole Feather as Substrate in a Submerged Fermentation
}

\author{
Ana Maria Mazotto, ${ }^{1}$ Rosalie Reed Rodrigues Coelho, ${ }^{1}$ Sabrina Martins Lage Cedrola, ${ }^{1}$ \\ Marcos Fábio de Lima, ${ }^{2}$ Sonia Couri, ${ }^{3}$ Edilma Paraguai de Souza, ${ }^{1}$ \\ and Alane Beatriz Vermelho ${ }^{1}$ \\ ${ }^{1}$ Departamento de Microbiologia Geral, Instituto de Microbiologia Paulo de Góes (IMPPG), Bloco I, Centro de Ciências da Saúde \\ (CCS), Universidade Federal do Rio de Janeiro (UFRJ), Cidade Universitária, Ilha do Fundão, 21941-590 Rio de Janeiro, RJ, Brazil \\ ${ }^{2}$ Centro de Pesquisas Avicolas, Instituto Federal do Rio de Janeiro, Campus Pinheiral, Rua José Breves, \\ $N^{\circ}$ 550, Centro, 27197-000 Pinheiral, RJ, Brazil \\ ${ }^{3}$ Instituto Federal de Educação Ciência e Tecnologia do Rio de Janeiro, Campus Rio de Janeiro, \\ Rua Senador Furtado $n^{\circ}$ 121, 20270-021 Maracanã, RJ, Brazil
}

Correspondence should be addressed to Alane Beatriz Vermelho, abvermelho@micro.ufrj.br

Received 12 April 2011; Accepted 27 May 2011

Academic Editor: Claudiu T. Supuran

Copyright (C) 2011 Ana Maria Mazotto et al. This is an open access article distributed under the Creative Commons Attribution License, which permits unrestricted use, distribution, and reproduction in any medium, provided the original work is properly cited.

\begin{abstract}
Three Bacillus species (B. subtilis LFB-FIOCRUZ 1270, B. subtilis LFB-FIOCRUZ 1273, and B. licheniformis LFB-FIOCRUZ 1274), isolated from the poultry industry, were evaluated for keratinase production using feathers or feather meal as the sole carbon and nitrogen sources in a submerged fermentation. The three Bacillus spp. produced extracellular keratinases and peptidases after 7 days. Feather meal was the best substrate for keratinase and peptidase production in B. subtilis 1273, with $412 \mathrm{U} / \mathrm{mL}$ and $463 \mathrm{U} / \mathrm{ml}$. The three strains were able to degrade feather meal (62-75\%) and feather (40-95\%) producing 3.9-4.4 mg/ml of soluble protein in feather meal medium and $1.9-3.3 \mathrm{mg} / \mathrm{ml}$ when feather medium was used. The three strains produced serine peptidases with keratinase and gelatinase activity. B. subtilis 1273 was the strain which exhibited the highest enzymatic activity.
\end{abstract}

\section{Introduction}

Feather waste is a byproduct of the domestic poultry industry and is $90 \%$ keratin $[1,2]$. However, the use of feather waste as a dietary protein supplement for animal feedstuffs is only carried out on a limited basis, due to its poor digestibility [3]. Keratin is an insoluble protein and is resistant to degradation by common peptidases, such as trypsin, pepsin, and papain $[4,5]$. This resistance is due to the constituent amino acid composition and configuration that provide structural rigidity. The mechanical stability of keratin and its resistance to biochemical degradation depend on the tightly packed protein chains in $\alpha$-helix ( $\alpha$-keratin) and $\beta$-sheet ( $\beta$-keratin) structures. In addition, these structures are cross-linking by disulfide bridges in cystines residues $[3,4,6]$.

A current value-added use for feathers is the conversion to feather meal using physical and chemical treatments.
However these methods can destroy certain heat-sensitive amino acids, such as methionine, lysine, and tryptophan, generating other nonnutritive amino acids, for instance, lanthionine and lysinoalanine [7].

An alternative and attractive method for improving the digestibility of feathers or feather meal is biodegradation by keratinolytic microorganisms $[8,9]$. A number of keratinolytic microorganisms can produce keratinases (E.C. 3.4.99.11), peptidases which are capable of degrading keratin. Various authors have reported that, among the keratinolytic microorganisms, some species of Bacillus [10$12]$, actinomycetes $[9,13,14]$, and fungi [15-17] are able to produce these keratinases and peptidases.

Biodegradation of poultry waste by keratinases is an environment friendly biotechnological process, which converts this abundant waste into low-cost, nutrient-rich animal feed $[18,19]$. Keratinolytic enzymes have applications in 
the detergent, medical, cosmetic, and leather industries; they can also be used in prion degradation and as pesticides $[11,20,21]$.

In the present work, the production of keratinases and peptidases by three Bacillus species isolated from poultry waste was investigated. Considering that the presence of keratinous substrates usually induces keratinase production, the main aim of the study was to compare the influence of feather or feather meal on the production of keratinolytic enzymes by three Bacillus spp.

\section{Materials and Methods}

2.1. Isolation, Selection, and Maintenance Procedures. Poultry residues, including feathers, feather meal, and other materials, obtained from a poultry industry (Rica Alimentos, Brazil), were added at $1 \%$ to modified Sabouraud (glucose $2.0 \%$, peptone $1.0 \%$, yeast extract $0.5 \%$ ) or yeast extractpeptone-sucrose (yeast extract $0.5 \%$, peptone $0.5 \%, \mathrm{KCl}$ $2.0 \%$, sucrose $2.0 \%$ ) liquid media. After 48 hours at $28^{\circ} \mathrm{C}$, a loopful of the growing microorganism was streaked on the same solid media above containing agar $(2.0 \%)$ and incubated for 72 hours at $28^{\circ} \mathrm{C}$. The isolated colonies were inoculated for 28 days at $28^{\circ} \mathrm{C}$ in tubes containing saline $(\mathrm{NaCl} 0.85 \%)$ and a single feather. The microorganisms which were able to grow in these conditions were transferred to yeast extract-peptone-sucrose solid medium slants, cultivated for 48 hours at $28^{\circ} \mathrm{C}$ and then maintained at $4^{\circ} \mathrm{C}$.

2.2. Bacillus sp. Identification. The microorganisms were identified at the Bacterial Physiology Laboratory, Bacteriology Department, Fundação Oswaldo Cruz, Brazil, by Jeane Quintanilha and Dr. Leon Rabinovitch, based on cell morphology, physiological characteristics, and biochemical analysis. They were deposited at the Coleção de Culturas do Gênero Bacillus e Gêneros Correlatos, CCGB (which is affiliated to the World Federation of Culture Collections) located at the Oswaldo Cruz Foundation, Brazil.

2.3. Inoculum Preparation. Erlenmeyer flasks ( $125 \mathrm{~mL})$ containing $25 \mathrm{ml}$ of yeast extract-peptone liquid media were inoculated with a loopful of each strain and incubated at $26 \pm 1^{\circ} \mathrm{C}$ and $300 \mathrm{rev} / \mathrm{min}$ for 72 hours. After centrifugation $\left(2000 \mathrm{~g} / 20 \mathrm{~min}\right.$ at $\left.26^{\circ} \mathrm{C}\right)$ and washing twice with saline, each pellet was further used.

2.4. Keratin Substrate. Chicken feathers obtained from poultry waste were washed extensively with water, and anionic detergent, dried at $60^{\circ} \mathrm{C}$ overnight, delipidated with chloroform: methanol $(1: 1, \mathrm{v} / \mathrm{v})$, and dried again at $60^{\circ} \mathrm{C}$. Feather meal was provided by Rica Alimentos industry.

The keratin for analytical analyses was obtained by the method described by Wawrzkiewicz et al. [22] modified. Briefly, $10 \mathrm{~g}$ of feathers were heated with a reflux condenser at $100^{\circ} \mathrm{C}$ for $80-120 \mathrm{~min}$ with $500 \mathrm{~mL}$ of DMSO. Keratin was then precipitated by the addition of two volumes of acetone and maintained at $4^{\circ} \mathrm{C}$ for $24-48$ hours. The keratin precipitates were collected by centrifugation $(2 \mathrm{x}$

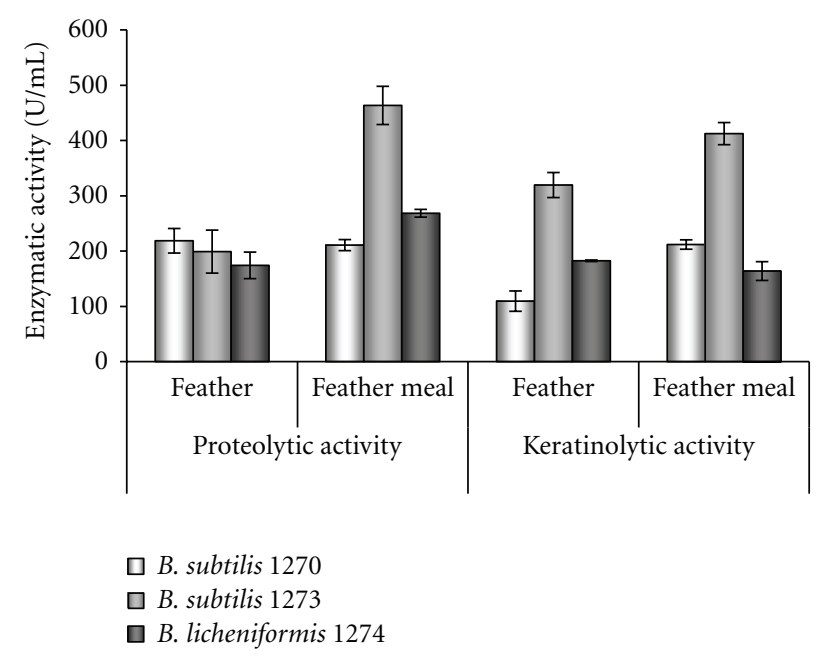

FIgURE 1: Proteolytic and keratinolytic activity of B. subtilis 1270, B. subtilis 1273 , and B. licheniformis 1274 after being grown ( 7 days at $28^{\circ} \mathrm{C}$ ) in feathers or feather meal media.

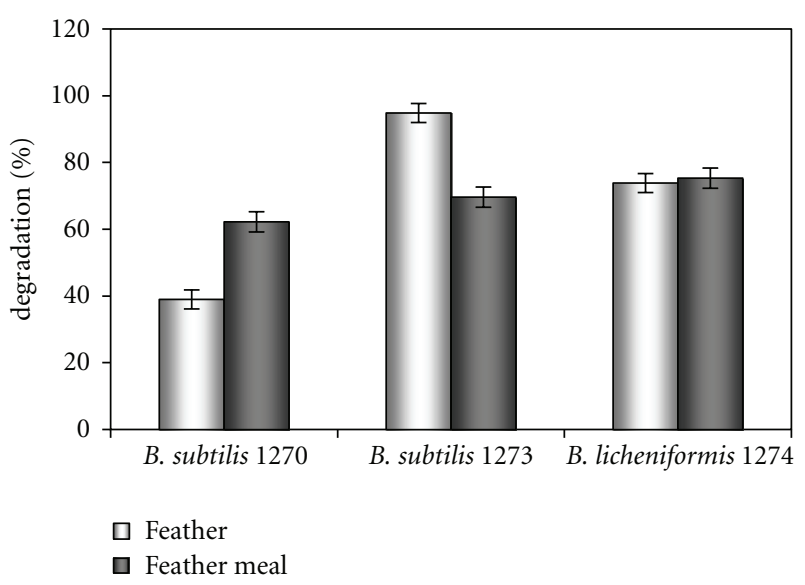

FIGURE 2: Substrate degradation by B. subtilis 1270, B. licheniformis 1274 , and B. cereus 1274 after 7 days of cultivation at $28^{\circ} \mathrm{C}$ in feathers or feather meal media.

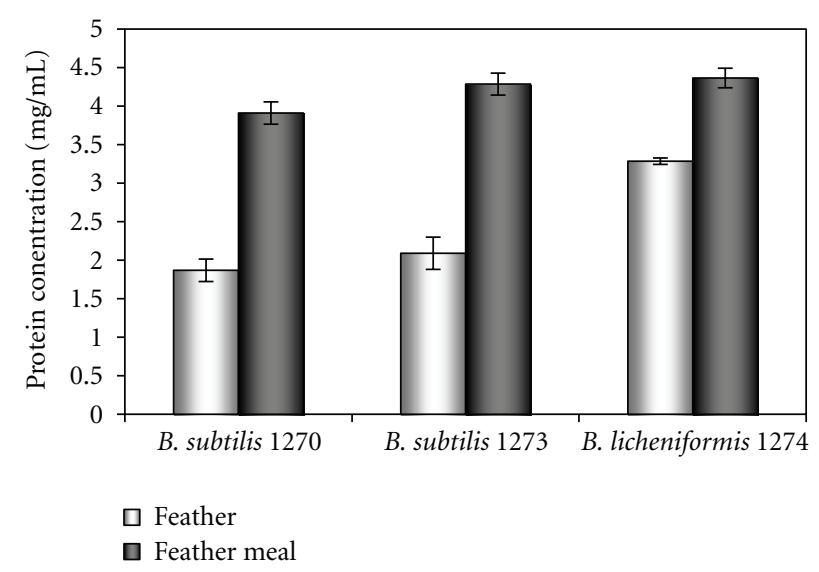

FIgURE 3: Protein concentration in culture supernatant of B. subtilis 1273 , B. licheniformis 1274 , and B. cereus 1268 grown in feathers and feather meals media at $28^{\circ} \mathrm{C}$ for 7 days. 


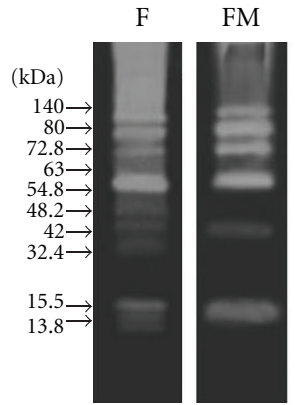

B. subtilis 1270

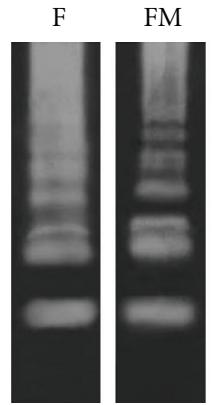

B. subtilis 1273

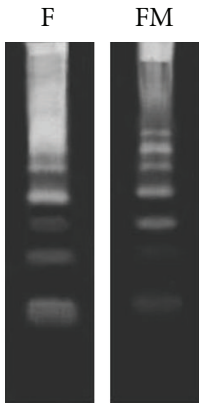

B. licheniformis 1274

(a)

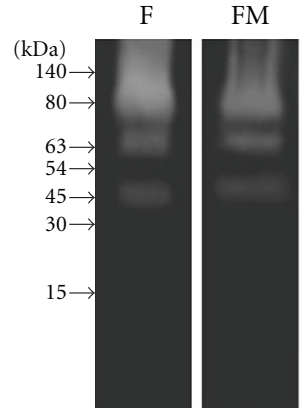

B. subtilis 1270

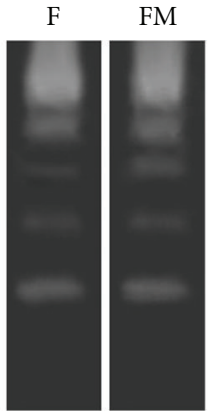

B. subtilis 1273

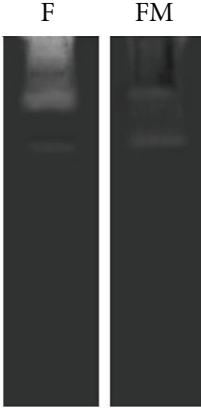

B. licheniformis 1274

(b)

Figure 4: Gelatin (a) and keratin (b) zymogram analysis of extracellular peptidases from B. subtilis 1270, B. subtilis 1273, B. licheniformis 1274 grown in feather (F) or feather meal medium (FM). Gel strips containing concentrated culture supernatant were incubated for $48 \mathrm{~h}$ at $37^{\circ} \mathrm{C}$ in citric acid buffer $\mathrm{pH}$ 5.0. The approximate molecular mass of the peptidases is shown on the left.
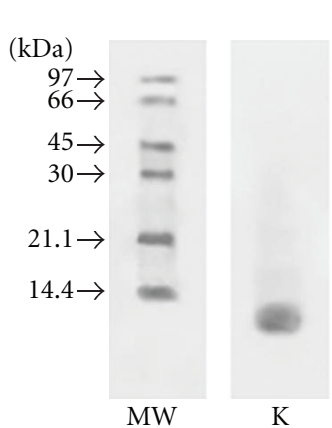

B. subtilis 1270

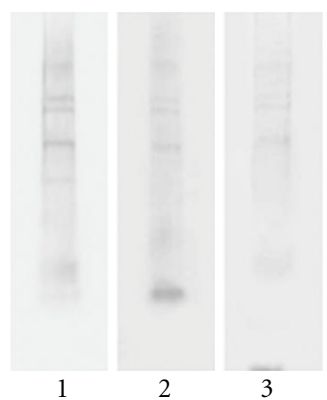

B. subtilis 1273

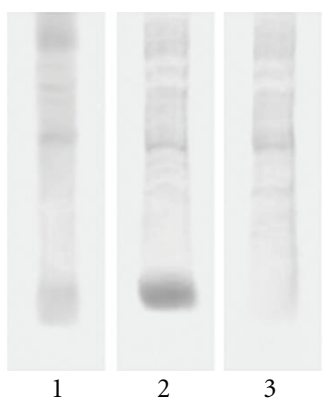

B. licheniformis 1274

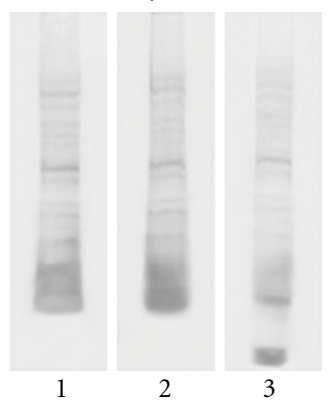

FIGURE 5: Cleavage of keratin substrate by extracellular peptidase activities of Bacillus sp. analysed by SDS-PAGE. K keratin; 1: supernatant control; 2: reaction mixture containing keratin and enzymatic extract before incubation; 3: reaction mixture after 1 hour of incubation at $37^{\circ} \mathrm{C}$. Numbers on the left indicate relative molecular mass markers $(\mathrm{kDa})$. Phosphorylase b $(94 \mathrm{kDa})$, bovine serum albumin $(67 \mathrm{kDa})$, ovalbumin $(43 \mathrm{kDa})$, carbonic anhydrase $(30 \mathrm{kDa})$, soybean trypsin inhibitor $(20.1 \mathrm{kDa})$, and $\alpha$-lactalbumin $(14.4 \mathrm{kDa})$ were used as molecular mass standards.

$2000 \mathrm{~g} / 15 \mathrm{~min}$ ), washed twice with distilled water and dried at $4^{\circ} \mathrm{C}$. The white powder obtained correspond to the keratin substrate [11].

\subsection{Keratinase Production. Fermentations were carried out} by seeding the inoculum preparation (item 2.3) into Erlenmeyer flasks $(250 \mathrm{~mL})$ containing a liquid medium $(100 \mathrm{~mL})$ composed of a mineral salt solution $\left(\mathrm{Na}_{2} \mathrm{HPO}_{4} .7 \mathrm{H}_{2} \mathrm{O} 0.06 \mathrm{M}\right.$ $72 \mathrm{~mL}, \mathrm{KH}_{2} \mathrm{PO}_{4} 0.06 \mathrm{M} 28 \mathrm{~mL}, \mathrm{pH} 7.2$ ), $0.01 \%$ yeast extract and two substrates as the main carbon and nitrogen source: feathers or feather meal at $1 \%$. After incubation for 7 days at $26 \pm 1{ }^{\circ} \mathrm{C}$ under shake conditions $(300 \mathrm{rpm})$ the media were centrifuged $(2000 \mathrm{~g} / 20 \mathrm{~min})$. The supernatant was the source of enzymatic extract and was used for keratinase and gelatinase activity assays and in the zymographic and enzymographic analysis. For electrophoresis experiments supernatants were concentrated twenty times in dialyzing membranes (cut off $9000 \mathrm{Da}$ ) against polyethylene glycol 4000 , overnight at $4^{\circ} \mathrm{C}$.

2.6. Feather and Feather Meal Degradation. The percentage of substrate degradation was measured by weight loss. The feathers and feather meal still present in medium after the cultivation period were filtered through Whatman $\mathrm{n}^{\circ} 1$ filter paper, thoroughly washed, with $70 \%$ alcohol, oven dried at $60^{\circ} \mathrm{C}$ for 48 hours, and finally weighed to determine weightloss.

2.7. Enzymatic Activity. Keratinase activity was measured according to Grzywnowicz et al. [23]. The reaction mixture contained $1.0 \mathrm{~mL}$ of the culture supernatant diluted five times and $1.5 \mathrm{~mL}$ of $0.67 \%(\mathrm{w} / \mathrm{v})$ keratin suspension in phosphate buffer $0.1 \mathrm{M}, \mathrm{pH}$ 7.4. After 1 hour of incubation at $37^{\circ} \mathrm{C}$ the reaction was interrupted by the addition of $1 \mathrm{ml}$ trichloroacetic acid $10 \%$ and placed in a refrigerator at $4^{\circ} \mathrm{C}$ for 30 minutes. An enzyme control was prepared by the addition of $1 \mathrm{ml}$ trichloroacetic before incubation. The reaction mixture was centrifuged $(2000 \mathrm{~g} / 10 \mathrm{~min})$ and read at $280 \mathrm{~nm}$ in a spectrophotometer. One unit of keratinase activity was defined as the amount of enzyme required to produce an absorbance increase of 0.01 under the described assay conditions.

Gelatinase activity was measured in systems containing $100 \mu \mathrm{L}$ culture supernatant, $400 \mu \mathrm{L}$ phosphate buffer $0.1 \mathrm{M}$ 


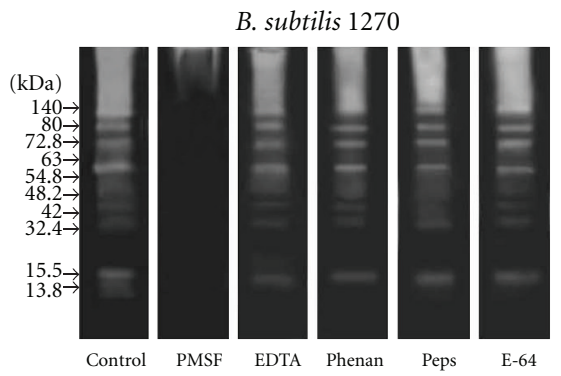

$(\mathrm{kDa})$

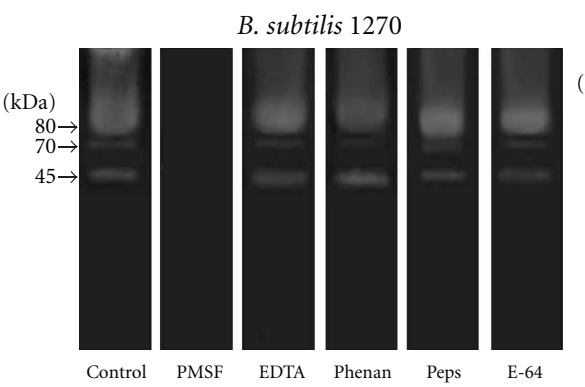

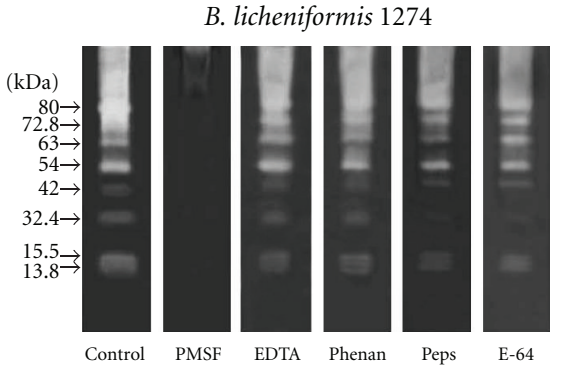

B. subtilis 1273

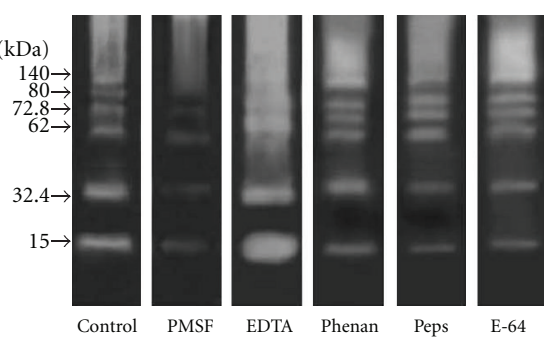

(a)
B. licheniformis 1274

B. subtilis 1273

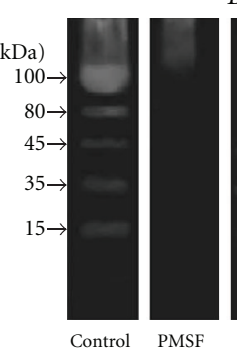

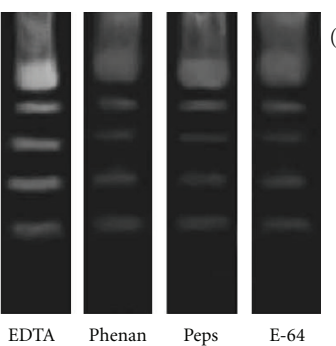

B. licheniformis 1274

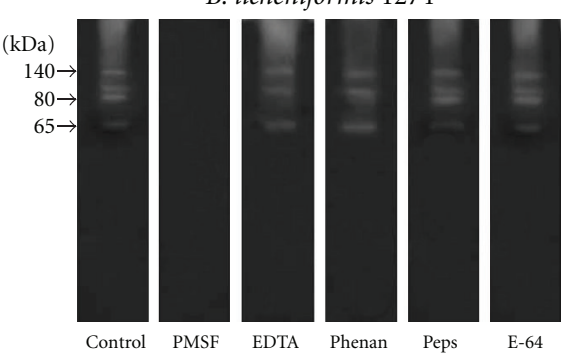

(b)

FIGURE 6: Effect of proteolytic inhibitors on the extracellular gelatinases (a) and keratinases (b) of Bacillus sp. grown in feather medium for 7 days at $28^{\circ} \mathrm{C}$. Gel strips containing concentrated culture supernatant were incubated for $48 \mathrm{~h}$ at $37^{\circ} \mathrm{C}$ in proteolysis buffer $(0.1 \mathrm{M}$ citric acid buffer $\mathrm{pH}$ 5.0) in the absence (control) or in the presence of different proteolytic inhibitors: 3 mmoL $1^{-1}$ phenylmethylsulfonyl fluoride (PMSF), $0.26 \mathrm{mmoL} \mathrm{l}^{-1}$ ethylenediaminetetraacetic acid (EDTA), $10 \mathrm{mmoL} \mathrm{l}^{-1} 1,10$ phenanthroline (Phenan), $10 \mu \mathrm{moL}{ }^{-1} \mathrm{pepstatin}$ A (Peps), and $5 \mu \mathrm{moL} \mathrm{I}^{-1} \mathrm{M}$ transepoxysuccinyl L-leucylamido-(4-guanidino) butane (E-64).

$\mathrm{pH} 7.4$, and $750 \mu \mathrm{L}$ gelatin $1 \%$. After incubation at $37^{\circ} \mathrm{C}$ for 30 minutes, $375 \mu \mathrm{L}$ of this solution was mixed with $500 \mu \mathrm{L}$ isopropanol, refrigerated at $4^{\circ} \mathrm{C}$ for 15 minutes, centrifuged (2000 g/15 min), and $100 \mu \mathrm{L}$ of the supernatant was used to measured the amount of protein by the Lowry method [24, 25]. One unit of gelatinase activity was defined as the amount of enzyme required to produce $1 \mu \mathrm{g}$ of peptides under the described assay conditions.

2.8. Protein Content. This was determined in the culture supernatants according to Lowry et al. [25], using albumin bovine serum as the standard. Readings were carried out in a spectrophotometer at $660 \mathrm{~nm}$.

2.9. Enzymography. Keratin degradation was evaluated by adding $20 \mu \mathrm{L}$ of the concentrated supernatant (containing $5 \mu \mathrm{g}$ proteins) to $5 \mu \mathrm{g}$ keratin and $20 \mu \mathrm{L}$ of distilled water. The reaction mixture was incubated for 1 hour at $37^{\circ} \mathrm{C}$. The presence of keratin and other proteinaceous material was detected by SDS-PAGE. After incubation, the reaction mixture was diluted in $40 \mu \mathrm{L}$ sample buffer (Tris- $\mathrm{HCl} 0.15 \mathrm{M}$ pH 6.8, SDS 0.5\%, glycerol 10.8\% v/v, 3\% 2-mercaptoetanol and bromophenol blue $0.1 \%$ ), heated at $100^{\circ} \mathrm{C}$ for 5 minutes, and then $30 \mu \mathrm{L}$ was applied to $15 \%$ polyacrylamide gel [26]. Runs were performed at $170 \mathrm{~V}$ for 2.5 hours at $26^{\circ} \mathrm{C}$. The gels were stained with Coomassie Brilliant Blue R250 ( $5 \mathrm{~mL}$ stock solution of coomassie blue 2\% w/v; $4 \mathrm{~mL}$ acetic acid; $20 \mathrm{~mL}$ methanol and $11 \mathrm{~mL}$ distilled water) overnight. Then the gels were decolorized with a methanol: acetic acid: water solution $(50: 10: 40 \mathrm{v} / \mathrm{v} / \mathrm{v})$ under agitation $(70 \mathrm{rpm})$, until the bands appeared.

2.10. Zymograms. The concentrated culture supernatant was mixed with the peptidase sample buffer [Tris- $\mathrm{HCl} 0.32 \mathrm{M}$, pH 6.8; glycerol 48\% (v/v); SDS 8\% (w/v) and bromophenol blue $0.06 \%(\mathrm{w} / \mathrm{v})]$ in a $6: 4$ proportion. Samples were applied to $12.5 \%$ polyacrylamide gel (staking gel $5 \%$ ) containing $0.1 \%(\mathrm{w} / \mathrm{v})$ gelatin or keratin copolymerized $[26,27]$. Runs were performed at $170 \mathrm{~V}$ for 2.5 hours at $4^{\circ} \mathrm{C}$. After the runs the gels were washed twice with Triton-X 2.5\% (v/v) for 15 minutes under agitation $(70 \mathrm{rpm})$ to remove SDS and then incubated for 48 hours at $37^{\circ} \mathrm{C}$ in citric acid buffer $\left(48.5 \mathrm{~mL}\right.$ citric acid $0.1 \mathrm{M}$ and $51.5 \mathrm{~mL} \mathrm{Na} \mathrm{NPO}_{4}$ $0.2 \mathrm{M}$ ), $\mathrm{pH}$ 5.0. For proteolytic detection the gels were incubated in coomassie blue as described above, overnight, and decolorized with methanol: acetic acid: water $(50: 10: 40$ $\mathrm{v} / \mathrm{v} / \mathrm{v})$, under agitation, until clearing of the degrading bands.

2.11. Effect of Inhibitors on Peptidase and keratinase Activity. The concentrated culture supernatants were submitted to zymography, as described above, with gelatin or keratin as substrates copolymerized. The gels were incubated for $48 \mathrm{~h}$ in proteolysis buffer $(0.1 \mathrm{M}$ citric acid buffer $\mathrm{pH} 5.0)$ containing $3 \mathrm{mM}$ phenylmethylsulfonyl fluoride (PMSF), $0.26 \mathrm{mM}$ ethylenediaminetetraacetic acid (EDTA), $10 \mathrm{mM} 1$ 
1,10 phenanthroline, $10 \mu \mathrm{M}$ pepstatin $\mathrm{A}$, and $5 \mu \mathrm{M}$ transepoxysuccinyl l-leucylamido-(4-guanidino) butane (E-64).

\section{Results and Discussion}

3.1. Isolation, Selection, and Characterization of Keratinolytic Bacillus sp. Seventeen different keratinolytic microorganisms were isolated from poultry waste in decomposition. After cultivation in minimal medium with feather as the sole carbon and nitrogen source, three isolates, presenting a pronounced growth and feather degradation, were selected and identified as Bacillus subtilis LFB-FIOCRUZ 1270, B. subtilis LFB-FIOCRUZ 1273, and B. licheniformis LFBFIOCRUZ 1274 and deposited in culture collection of Fundação Oswaldo Cruz (Coleção de Culturas do Gênero Bacillus e Gêneros Correlatos-FIOCRUZ), in Brazil.

\subsection{Influence of Keratin Substrate on Keratinase and Peptidase} Production. Extracellular keratinase and peptidases were obtained after growth of the Bacillus sp. on the culture medium containing feathers or feather meal as the sole carbon and nitrogen sources. Both keratin substrates present low digestibility however they could be an important protein source for animal feed after enzymatic hydrolysis of keratin [28]. The three microorganisms were able to produce keratinases and peptidases after 7 days of fermentation. Feather meal was the best substrate for keratinase production with $B$. subtilis 1270 . No significant difference was observed in the keratinolytic activity when B. licheniformis 1274 was cultivated in feather or feather meal media. B. subtilis 1273 presented the highest level of keratinase and peptidase activity with $319 \mathrm{U} / \mathrm{mL}$ of keratinases in feathers and $412 \mathrm{U} / \mathrm{mL}$ in feather meal and $450 \mathrm{U} / \mathrm{mL}$ of peptidases in feather meal (Figure 1). Peptidase production using feathers was the same for the three Bacillus (around $200 \mathrm{U} / \mathrm{mL}$ ) (Figure 1).

There are only a few studies that have used feather meal as a substrate for microbial fermentation, and according to the results obtained this substrate is a keratin-rich substrate supporting microbial growth in culture medium $[2,29,30]$. Additionally the percentage of degradation of feather, or feather meal by the three stains, was evaluated. B. subtilis 1273 degraded $70 \%$ and $95 \%$ of feather meal and feather, respectively (Figure 2). B. subtilis 1273 supernatant presented the highest peptidase and keratinase activity with feather meal with $463 \mathrm{U} / \mathrm{mL}$ and $412 \mathrm{U} / \mathrm{mL}$, respectively. Protein content was highest with feather meal $(3.9-4.4 \mathrm{mg} / \mathrm{mL})$. With feathers, $1.9-3.3 \mathrm{mg} / \mathrm{mL}$ were obtained for all Bacillus sp. (Figure 3).

Son et al. [31] investigated the keratinase production and keratin degradation by B. pumilus F3-4 after 7 days of incubation with different keratin substrates. Feather meal was the most degraded (97\%) and induced higher keratinase activity. The ability of a microorganism to degrade keratin and the resulting levels of keratinase produced vary according to the specie, chemical composition, the molecular structure of keratin substrates, and the culture conditions $[31,32]$.
3.3. Gelatin and Keratin Zymograms. All Bacillus sp. showed major peptidases migrating at 13.8 to $140 \mathrm{kDa}$. The differences observed were quantitative (Figure 4(a)). Keratinases were detected in a range of $45-80 \mathrm{kDa}$ in $B$. subtilis 1270 , $15-100 \mathrm{kDa}$ in B. subtilis 1273 , and $63-140 \mathrm{kDa}$ in $B$. licheniformis 1274 (Figure 4). B. licheniformis 1274 in feathers or feather meal presented the lowest keratinases activity (Figure 4(b)).

Keratinases with molecular masses ranging from 15 to $240 \mathrm{kDa}$ have been reported [33]; however the majority of keratinases presented molecular masses varying from 20 to $50 \mathrm{kDa}$ [34]. Our group previously showed multiple peptidases and keratinase (15-200 kDa) by other Bacillus sp. $[11,27]$.

Extracellular keratinases of other Bacillus such as $B$. subtilis strain KS-1, B. pseudofirmus strain FA30-01, B. pumilus, and $B$. cereus have been described secreting single polypeptides with a molecular mass of $25.4,27,65$, and 45 $\mathrm{kDa}$, respectively $[8,10,12,35]$.

Enzymographic analysis using keratin substrate (Figure 5) demonstrated that the enzymatic extract obtained from the Bacillus was able to hydrolyze keratin. Protein bands with a molecular mass of $10 \mathrm{kDa}$ corresponding to feather keratin were detected in SDS-PAGE after incubation with the enzymatic extract.

3.4. Determination of Peptidase and Keratinase Classes. Inhibition tests demonstrated that all peptidases including keratinases are serine peptidases (Figure 6). Most of keratinases described, particularly those produced by Bacillus, are serine peptidase, and some of them belong to the subtilisin family [36]. Keratinases of B. cereus and B. pseudofirmus FA30-01, and $B$. pumilus were completely inhibited by PMSF $[3,10$, 35]. In the Bacillus genus a secreted metallopeptidase has been described by Werlang and Brandelli [37].

\section{Conclusions}

In this work we described the isolation and identification of three new keratinolytic Bacillus sp. Feather and feather meal were used in a submerged fermentation in order to obtain the peptidases. It is interesting to note that the occurrence of peptidases was more prominent in the presence of feather meal. These results showed the potential of feather meal as a substrate for microbial fermentation. Microorganisms isolated in this study present potential for biotechnological uses. The B. subtilis 1273 was the most efficient in keratin degradation. Its enzymes could be used as additives in animal feed to improve feather meal digestibility.

\section{Acknowledgments}

The authors would like to thank the technical assistance of Ms. Denise da Rocha de Souza, supported by fellowships from MCT/CNPq. Research is supported by CAPES, FAPERJ, MCT/CNPq, and Conselho de Ensino para Graduados e Pesquisas (CEPG/UFRJ). 


\section{References}

[1] A. Gessesse, R. Hatti-Kaul, B. A. Gashe, and B. Mattiasson, "Novel alkaline proteases from alkaliphilic bacteria grown on chicken feather," Enzyme and Microbial Technology, vol. 32, no. 5, pp. 519-524, 2003.

[2] J. D. Liang, Y. F. Han, J. W. Zhang, W. Du, Z. Q. Liang, and Z. Z. Li, "Optimal culture conditions for keratinase production by a novel thermophilic Myceliophthora thermophila strain GZUIFR-H49-1," Journal of Applied Microbiology, vol. 110, no. 4, pp. 871-880, 2011.

[3] A. Ghosh, K. Chakrabarti, and D. Chattopadhyay, "Degradation of raw feather by a novel high molecular weight extracellular protease from newly isolated Bacillus cereus DCUW," Journal of Industrial Microbiology \& Biotechnology, vol. 35, no. 8, pp. 825-834, 2008.

[4] A. Riffel, A. Brandelli, C. M. Bellato, G. H. M. Souza, M. N. Eberlin, and F. C. A. Tavares, "Purification and characterization of a keratinolytic metalloprotease from Chryseobacterium sp. kR6," Journal of Biotechnology, vol. 128, no. 3, pp. 693-703, 2007.

[5] T. I. Zaghloul, A. M. Embaby, and A. R. Elmahdy, "Biodegradation of chicken feathers waste directed by Bacillus subtilis recombinant cells: scaling up in a laboratory scale fermentor," Bioresource Technology, vol. 102, no. 3, pp. 2387-2393, 2011.

[6] S. Yamamura, M. Yasutaka, H. Quamrul, K. Yokoyama, and E. Tamiya, "Keratin degradation: a cooperative action of two enzymes from Stenotrophomonas sp," Biochemical and Biophysical Research Communications, vol. 294, no. 5, pp. 1138-1143, 2002.

[7] N. R. Marcondes, C. L. Taira, D. C. Vandresen, T. I. E. Svidzinski, M. K. Kadowaki, and R. M. Peralta, "New featherdegrading filamentous fungi," Microbial Ecology, vol. 56, no. 1, pp. 13-17, 2008.

[8] H. J. Suh and H. K. Lee, "Characterization of a keratinolytic serine protease from Bacillus subtilis KS-1," Journal of Protein Chemistry, vol. 20, no. 2, pp. 165-169, 2001.

[9] D. G. Syed, J. C. Lee, W. Li, C. Kim, and D. Agasar, "Production, characterization and application of keratinase from Streptomyces gulbargensis," Bioresource Technology, vol. 100, no. 5, pp. 1868-1871, 2009.

[10] A. G. Kumar, S. Swarnalatha, S. Gayathri, N. Nagesh, and G. Sekaran, "Characterization of an alkaline active-thiol forming extracellular serine keratinase by the newly isolated Bacillus pumilus," Journal of Applied Microbiology, vol. 104, no. 2, pp. 411-419, 2008.

[11] A. M. Mazotto, A. C. N. de Melo, A. Macrae et al., "Biodegradation of feather waste by extracellular keratinases and gelatinases from Bacillus spp," World Journal of Microbiology and Biotechnology, vol. 27, no. 6, pp. 1355-1365, 2010.

[12] M. Kojima, M. Kanai, M. Tominaga, S. Kitazume, A. Inoue, and K. Horikoshi, "Isolation and characterization of a featherdegrading enzyme from Bacillus pseudofirmus FA30-01," Extremophiles, vol. 10, no. 3, pp. 229-235, 2007.

[13] L. A. I. De Azeredo, M. B. De Lima, R. R. R. Coelho, and D. M. G. Freire, "A low-cost fermentation medium for thermophilic protease production by Streptomyces sp. 594 using feather meal and corn steep liquor," Current Microbiology, vol. 53, no. 4, pp. 335-339, 2006.

[14] R. Tatineni, K. K. Doddapaneni, R. C. Potumarthi et al., "Purification and characterization of an alkaline keratinase from Streptomyces sp.", Bioresource Technology, vol. 99, no. 6, pp. 1596-1602, 2008.
[15] P. Anbu, S. C. B. Gopinath, A. Hilda, T. Lakshmipriya, and G. Annadurai, "Optimization of extracellular keratinase production by poultry farm isolate Scopulariopsis brevicaulis," Bioresource Technology, vol. 98, no. 6, pp. 1298-1303, 2007.

[16] A. M. Farag and M. A. Hassan, "Purification, characterization and immobilization of a keratinase from Aspergillus oryzae," Enzyme and Microbial Technology, vol. 34, no. 2, pp. 85-93, 2004.

[17] C. J. Singh, "Optimization of an extracellular protease of Chrysosporium keratinophilum and its potential in bioremediation of keratinic wastes," Mycopathologia, vol. 156, no. 3, pp. 151-156, 2003.

[18] S. Balaji, M. S. Kumar, R. Karthikeyan et al., "Purification and characterization of an extracellular keratinase from a hornmeal-degrading Bacillus subtilis MTCC (9102)," World Journal of Microbiology and Biotechnology, vol. 24, no. 11, pp. 2741-2745, 2008.

[19] A. A. Khardenavis, A. Kapley, and H. J. Purohit, "Processing of poultry feathers by alkaline keratin hydrolyzing enzyme from Serratia sp. HPC 1383," Waste Management, vol. 29, no. 4, pp. 1409-1415, 2009.

[20] S. Müller-Hellwig, M. H. Groschup, R. Pichner et al., "Biochemical evidence for the proteolytic degradation of infectious prion protein PrPsc in hamster brain homogenates by foodborne bacteria," Systematic and Applied Microbiology, vol. 29, no. 2, pp. 165-171, 2006.

[21] X. Y. Yue, B. Zhang, D. D. Jiang, Y. J. Liu, and T. G. Niu, "Separation and purification of a keratinase as pesticide against root-knot nematodes," World Journal of Microbiology and Biotechnology. In press.

[22] K. Wawrzkiewicz, J. Lobarzewski, and T. Wolski, "Intracellular keratinase of Trichophyton gallinae," Journal of Medical and Veterinary Mycology, vol. 25, no. 4, pp. 261-268, 1987.

[23] G. Grzywnowicz, J. Lobarzewski, K. Wawrzkiewicz, and T. Wolski, "Comparative characterization of proteolytic enzymes from Trichophyton gallinae and Trichophyton verrucosum," Journal of Medical and Veterinary Mycology, vol. 27, no. 5, pp. 319-328, 1989.

[24] L. B. Jones, D. Fontanini, M. Jarvinen, and A. Pekkarinen, "Simplified endoproteinase assays using gelatin or azogelatin," Analytical Biochemistry, vol. 263, no. 2, pp. 214-220, 1998.

[25] O. H. Lowry, N. J. Rosembrough, A. L. Farr, and R. J. Randall, "Protein measurement with the Folin phenol reagent," The Journal of biological chemistry, vol. 193, no. 1, pp. 265-275, 1951.

[26] U. K. Laemmli, "Cleavage of structural proteins during the assembly of the head of bacteriophage T4," Nature, vol. 227, no. 5259, pp. 680-685, 1970.

[27] A. M. Mazotto, S. M. L. Cedrola, U. Lins et al., "Keratinolytic activity of Bacillus subtilis AMR using human hair," Letters in Applied Microbiology, vol. 50, no. 1, pp. 89-96, 2010.

[28] A. Grazziotin, F. A. Pimentel, S. Sangali, E. V. de Jong, and A. Brandelli, "Production of feather protein hydrolysate by keratinolytic bacterium Vibrio sp. kr2," Bioresource Technology, vol. 98, no. 16, pp. 3172-3175, 2007.

[29] A. Bertsch and N. Coello, "A biotechnological process for treatment and recycling poultry feathers as a feed ingredient," Bioresource Technology, vol. 96, no. 15, pp. 1703-1708, 2005.

[30] E. Tiwary and R. Gupta, "Medium optimization for a novel $58 \mathrm{kDa}$ dimeric keratinase from Bacillus licheniformis ER15: biochemical characterization and application in feather degradation and dehairing of hides," Bioresource Technology, vol. 101, no. 15, pp. 6103-6110, 2010. 
[31] H. Son, H. Park, H. Kim, and C. Lee, "Nutritional regulation of keratinolytic activity in Bacillus pumilis," Biotechnology Letters, vol. 30, no. 3, pp. 461-465, 2008.

[32] C. Cai and X. Zheng, "Medium optimization for keratinase production in hair substrate by a new Bacillus subtilis KDN2 using response surface methodology," Journal of Industrial Microbiology and Biotechnology, vol. 36, no. 7, pp. 875-883, 2009.

[33] R. Gupta and P. Ramnani, "Microbial keratinases and their prospective applications: an overview," Applied Microbiology and Biotechnology, vol. 70, no. 1, pp. 21-33, 2006.

[34] P. Prakash, S. K. Jayalakshmi, and K. Sreeramulu, "Purification and characterization of extreme alkaline, thermostable keratinase, and keratin disulfide reductase produced by Bacillus halodurans PPKS-2," Applied Microbiology and Biotechnology, vol. 87, no. 2, pp. 625-633, 2010.

[35] F. Sousa, S. Jus, A. Erbel, V. Kokol, A. Cavaco-Paulo, and G. M. Gubitz, "A novel metalloprotease from Bacillus cereus for protein fibre processing," Enzyme and Microbial Technology, vol. 40, no. 7, pp. 1772-1781, 2007.

[36] X. Lin, D. W. Kelemen, E. S. Miller, and J. C. H. Shih, "Nucleotide sequence and expression of ker A, the gene encoding a keratinolytic protease of Bacillus licheniformis PWD-1," Applied and Environmental Microbiology, vol. 61, no. 4, pp. 1469-1474, 1995.

[37] P. O. Werlang and A. Brandelli, "Characterization of a novel feather-degrading Bacillus sp. strain," Applied Biochemistry and Biotechnology, vol. 120, no. 1, pp. 71-79, 2005. 

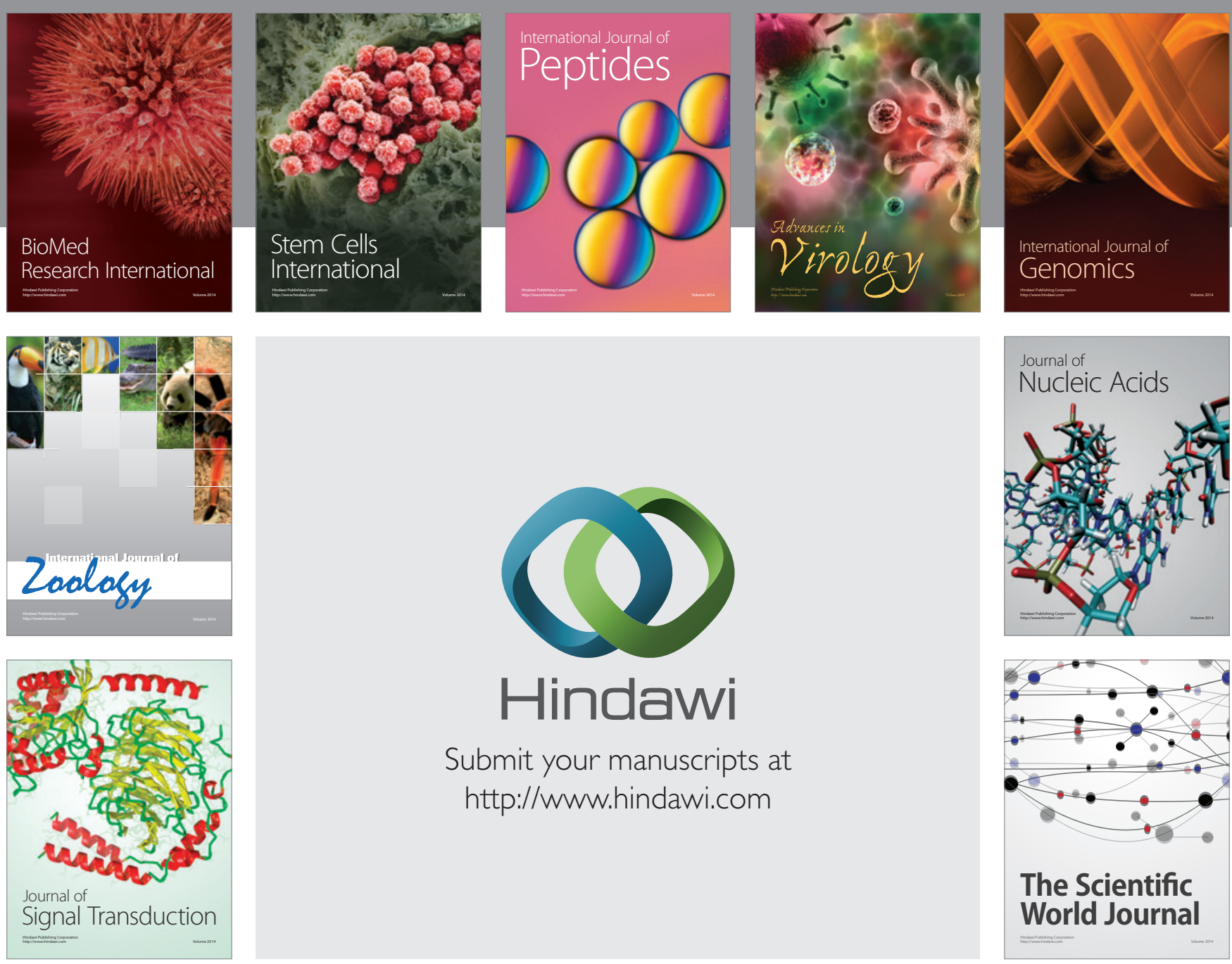

Submit your manuscripts at

http://www.hindawi.com
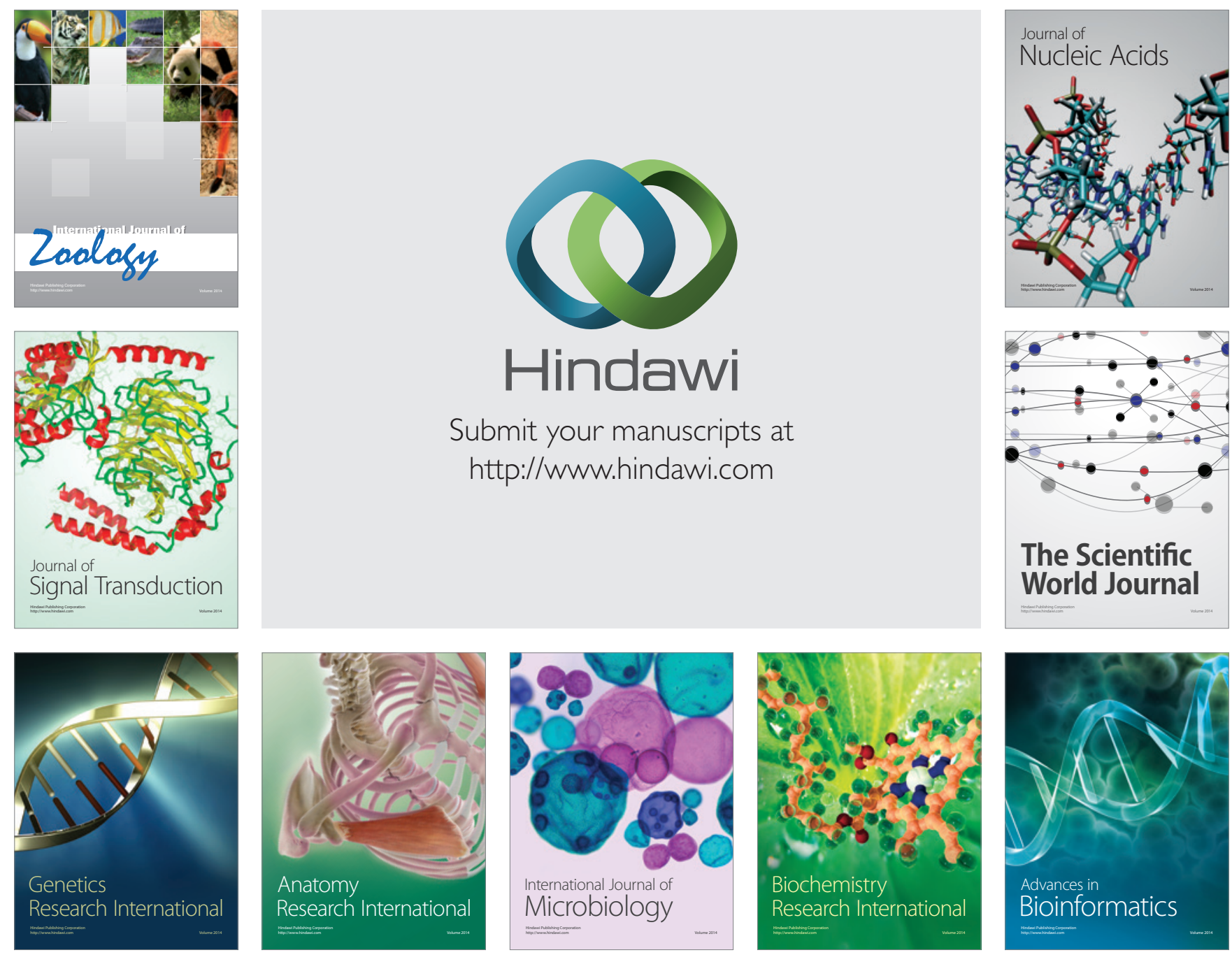

The Scientific World Journal
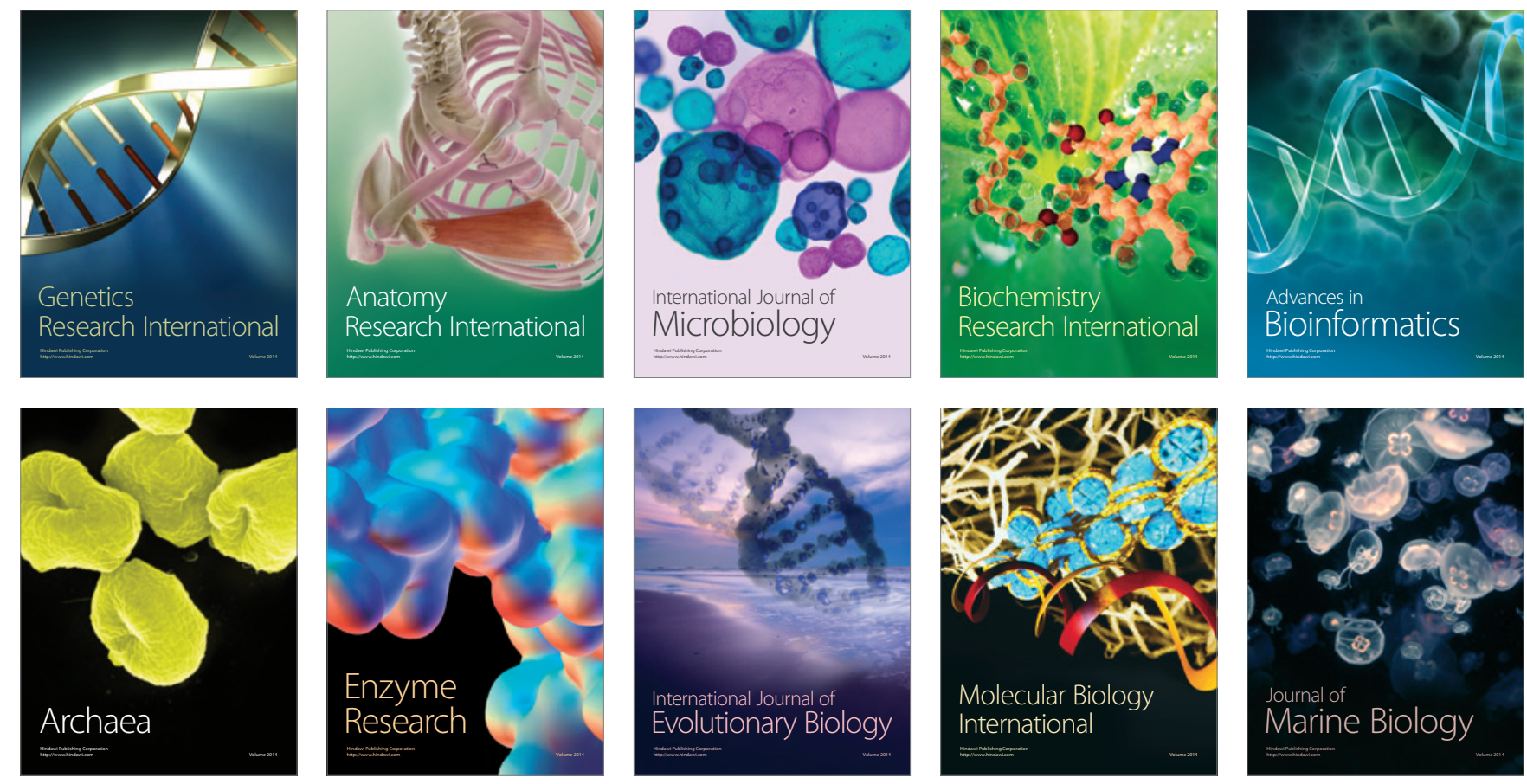